\title{
Penyuluhan Dampak Lama Waktu Membatik dengan Kejadian Carpal Tunnel Syndrome (CTS) di Kampoeng Batik Laweyan
}

\author{
Diah Kurnia Mirawati*, Pepi Budianto, Hanindya Riani Prabaningtyas, Stefanus Erdana Putra, \\ Muhammad Hafizhan, Wahyu Agung Susilo, Novian Anindito Santosa \\ KSM Ilmu Penyakit Saraf, Fakultas Kedokteran Universitas Sebelas Maret \\ E-mail korespondensi: diahkm@staff.uns.ac.id
}

\begin{abstract}
ABSTRAK
Pengabdian masyarakat berjudul "Penyuluhan Dampak Lama Waktu Membatik dengan Kejadian Carpal Tunnel Syndrome (CTS) di Kampoeng Batik Laweyan" bertujuan untuk meningkatkan pengetahuan dan kesadaran para pengrajin batik akan dampak negatif gerakan tangan yang repetitif atau berulang selama membatik dalam jangka waktu yang lama. Kegiatan ini juga bertujuan mengarahkan para pembatik untuk melakukan modifikasi posisi kerja yang ergonomis dalam proses membatik sehingga dapat mencegah timbulnya kejadian CTS. Target yang dicapai adalah peningkatan pemahaman dan informasi terkait dampak lama waktu membatik serta pencegahan kejadian CTS pada pembatik. Metode pelaksanaan kegiatan pemberdayaan dan pengabdian masyarakat pada mitra berupa pemetaan demografi pengrajin batik dengan cara mendata jumlah pembatik, jenis kelamin, umur, lama masa kerja sebagai pembatik, frekuensi gerakan repetitif pada pergelangan tangan, riwayat penyakit sebelumnya, pemeriksaan elektromiografi (EMG) gratis pada pembatik, dan analisa hasilnya. Selanjutnya, peneliti melakukan penyuluhan dengan cara menjelaskan hasil pemeriksaan EMG, dampak negatif yang ditimbulkan dari gerakan tangan repetitif dalam membatik, diskusi dan tanya jawab, edukasi posisi kerja yang ergonomis dalam membatik, serta evaluasi. Hasil pengabdian ini menunjukkan bahwa para pembatik memiliki pemahaman yang meningkat dibandingkan sebelum penyuluhan tentang hubungan lama waktu membatik dan dampak buruknya, sehingga meningkatkan kesadaran para pembatik akan kejadian CTS yang dapat timbul akibat posisi kerja yang tidak ergonomis.
\end{abstract}

Kata kunci: Carpal Tunnel Syndrome, pengabdian masyarakat, pengrajin batik, penyuluhan

\section{PENDAHULUAN}

Carpal Tunnel Syndrome (CTS) adalah salah satu gangguan saraf tepi yang paling banyak ditemukan dalam kehidupan sehari-hari karena terjadi penyempitan pada terowongan karpal, baik akibat pembengkakan fasia maupun akibat kelainan pada tulang-tulang kecil pergelangan tangan sehingga terjadi penekanan terhadap nervus medianus di pergelangan tangan. CTS diartikan sebagai kelemahan pada tangan yang disertai nyeri pada daerah distribusi nervus medianus. Nervus medianus yang berasal dari pleksus brachialis akan melewati terowongan karpal saat berjalan dari lengan bawah menuju ke tangan (Chan dkk., 2007).

CTS dapat terjadi baik pada kalangan masyarakat umum maupun pekerja industri. Prevalensinya sekitar 50 kasus per 1.000 subjek pada populasi umum. National Health Interview Study (NHIS) memperkirakan prevalensi CTS adalah 1,55\%. Sebagai salah satu dari tiga kelompok penyakit Cumulative Trauma Disorder (CTD) yang paling umum pada anggota gerak atas, prevalensi global CTS pada tahun 2012 adalah 40\% (Setyawan, 2017). Laporan International Labor Organization (ILO) menunjukkan bahwa CTS hampir selalu ditemukan di setiap kasus penyakit akibat kerja di beberapa negara. Pada tahun 2010 terjadi peningkatan jumlah kasus CTS akibat kerja sekitar 30\% dibandingkan tahun 2001 (International Labor Organization, 2013). Prevalensi kejadian CTS pada tenaga kerja di Indonesia belum dapat diketahui karena belum dilakukan survei terhadap topik ini. Namun, sebuah penelitian 
nasional yang dilakukan pada populasi pekerja berisiko tinggi dengan gerakan repetitif di pergelangan tangan, melaporkan prevalensi CTS 5,6\% hingga 15\% (Hakim dan Tjandra, 2016). Tingginya angka prevalensi ini tentunya diikuti dengan biaya yang tinggi untuk perawatan medis, rehabilitasi, kompensasi hilangnya jam kerja, biaya pensiun awal, juga pelatihan tenaga kerja baru, sehingga menjadikan CTS sebagai salah satu masalah utama di bidang ketenagakerjaan (Kurniawan dkk., 2008).

Industri batik yang ada di kota Surakarta mampu menyerap banyak tenaga kerja di masyarakat. Hal tersebut terlihat dari adanya beberapa pasar yang menjual batik, toko, ataupun destinasi wisata seperti Kampung Batik yang di dalamnya terdapat pabrik pembuatan batik. Pembuatan batik sendiri dibagi menjadi dua metode, yaitu industri batik yang menggunakan metode cap dan metode tulis. Keduanya memiliki keunggulan dan kelemahan masing-masing (Harlukinita dkk., 2014).

Pada pengerjaan batik tulis, proses produksi masih menggunakan alat tradisional yang disebut dengan canting. Proses pengerjaan batik tulis sendiri mirip dengan proses melukis, di mana kanvasnya adalah kain serta kuasnya adalah canting. Proses pengerjaan batik tulis memakan waktu yang lebih lama bila dibandingkan dengan batik cap. Hal tersebut bergantung pada tingkat kerumitan motif yang ada. Hal inilah yang sering mengakibatkan beberapa pekerja memiliki keluhan seperti kebas di telapak tangan ataupun mengeluhkan nyeri pada telapak tangan (Harlukinita dkk., 2014).

Penelitian yang dilakukan oleh Subandi dkk. (2020) menyatakan bahwa terdapat hubungan yang searah dan signifikan secara statistik $(r=0,572 ; p=0,001)$ antara tingkat keparahan CTS dengan lama masa kerja sebagai pembatik pada kelompok pengrajin di Kampoeng Batik Laweyan yang telah menekuni profesinya lebih dari lima tahun. Sementara itu, keluhan kebas atau nyeri pada pergelangan tangan tersebut juga berbanding lurus dengan lama masa kerja pembatik, tetapi tidak signifikan secara statistik $(\mathrm{p}=0,355)$.

\section{METODE PELAKSANAAN}

Subjek pada kegiatan pemberdayaan dan pengabdian masyarakat ini adalah pengrajin batik tulis yang ada di Kampoeng Batik Laweyan, Kota Surakarta, Jawa Tengah. Kawasan pusat batik tertua di Surakarta ini telah berdiri sejak 500 tahun yang lalu dan menjadi saksi bisu perjuangan pergerakan nasional bangsa Indonesia pada saat berdirinya Sarikat Dagang Islam oleh Haji Samanhudi di tahun 1912. Hingga saat ini 250 motif batik khas Kampoeng Batik Laweyan telah dipatenkan (Harlukinita dkk., 2014). Forum Kampoeng Batik Laweyan terbentuk melalui kerja sama lebih dari 50 gerai yang masing-masing memiliki 1-3 orang pengrajin batik. Keadaan profil pengrajin di Kampoeng Batik Laweyan sangat heterogen baik ditinjau dari segi usia, jenis kelamin, pendidikan terakhir, domisili, lama masa kerja, dan riwayat penyakit sebelumnya. Fokus dalam kegiatan ini adalah berusaha meningkatkan kesadaran dan pemahaman para pengrajin batik terkait dampak lama masa kerja sebagai pembatik serta pencegahan kejadian CTS.

Upaya untuk menyelesaikan permasalahan yang dihadapi oleh para pengrajin batik yaitu dengan penyuluhan tentang dampak posisi yang tidak ergonomis dalam jangka waktu yang lama dan pencegahan CTS dengan metode pendekatan sebagai berikut:

a. Koordinasi dengan pengurus forum Kampoeng Batik Laweyan dan pemetaan terhadap pembatik

Peneliti berkoordinasi dengan pengurus dan mendata jumlah pengrajin batik, jenis kelamin, umur, dan lama masa kerja sebagai pembatik

b. Melakukan pemeriksaan elektromiografi (EMG) gratis pada pengrajin batik

Dari sekitar 58 pengrajin batik yang telah didata, dipilih 30 orang secara acak untuk menjalani pemeriksaan EMG gratis sebagai dasar diagnosis tingkat keparahan CTS. Sebelum dilakukan pemeriksaan, peneliti juga melakukan wawancara singkat tentang frekuensi gerakan repetitif pada pergelangan tangan dan riwayat penyakit pengrajin batik sebelumnya. Riwayat penyakit yang ditanyakan meliputi riwayat kehamilan, diabetes mellitus, rheumatoid arthritis, tumor di pergelangan tangan, obesitas, dan riwayat trauma di pergelangan tangan.

c. Melakukan analisa hasil pemeriksaan 
d. Melakukan diseminasi hasil dengan pendidikan masyarakat

Penyuluhan dilakukan dengan cara menjelaskan hasil pemeriksaan EMG sebelumnya, dampak negatif yang ditimbulkan dari gerakan tangan repetitif yang tidak ergonomis dan dilakukan dalam jangka waktu yang panjang oleh para pengrajin batik, diskusi dan tanya jawab, serta edukasi posisi kerja yang ergonomis dalam membatik

e. Partisipasi mitra

Para pengrajin batik berperan aktif dalam diskusi materi dan sangat antusias untuk mempraktekkan posisi kerja yang ergonomis dan terbentuk tim edukasi dari para pengrajin untuk melakukan sosialisasi lanjutan kepada pengrajin batik yang belum hadir dalam penyuluhan.

f. Evaluasi

Sebelum pelaksanaan kegiatan dilakukan pretest tentang pengetahuan umum pengrajin terkait CTS dan posisi ergonomis dalam membatik dan setelah kegiatan dilakukan posttest terhadap pemahaman materi yang telah disampaikan.

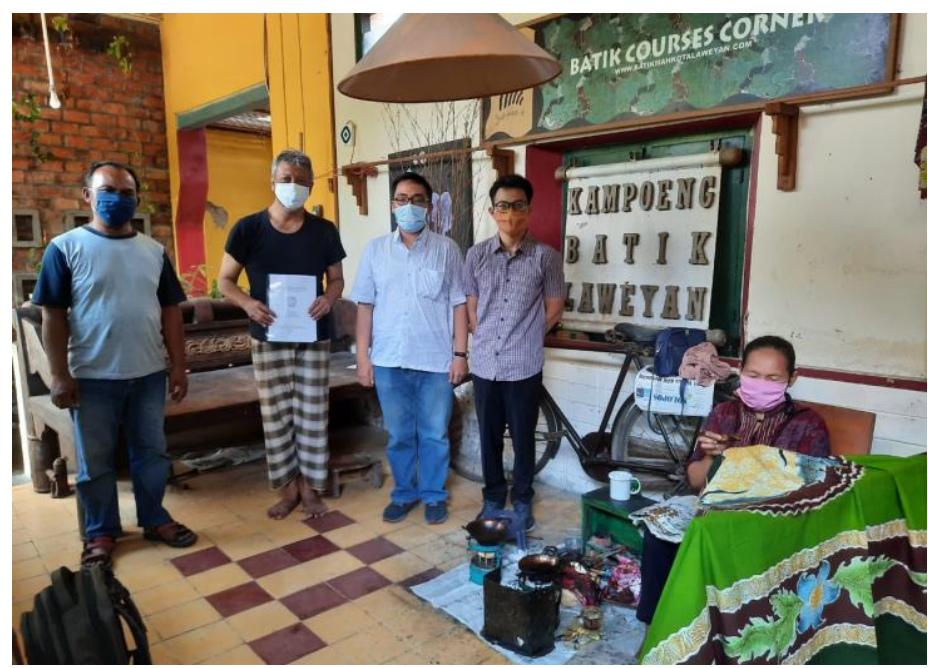

Gambar 1. Koordinasi dengan Forum Kampoeng Batik Laweyan

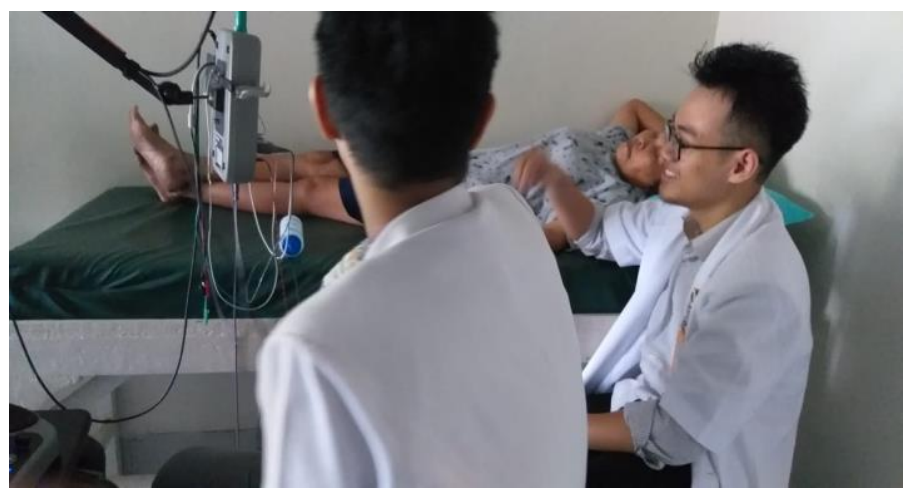

Gambar 2. Proses Pemeriksaan EMG Pengrajin Batik 


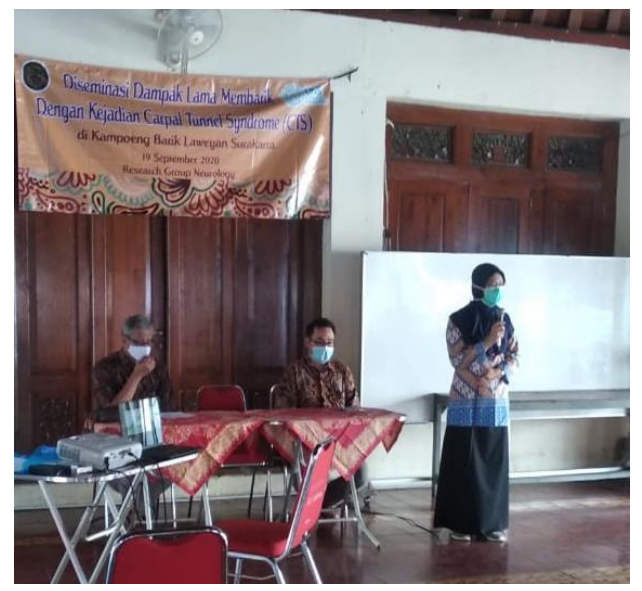

Gambar 3. Pembukaan Penyuluhan oleh Ketua Research Group

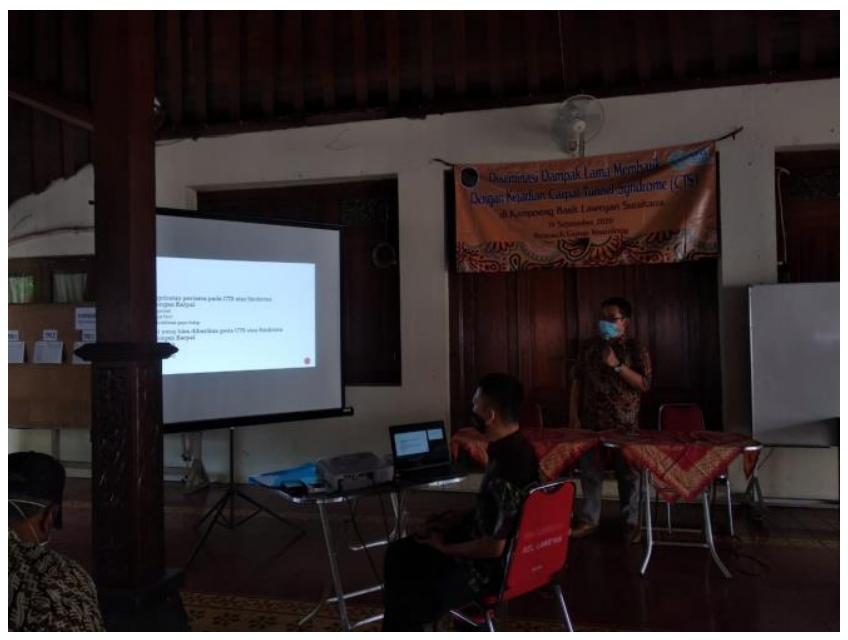

Gambar 4. Kegiatan Pretest Sebelum Penyuluhan dan Posttest Setelah Penyuluhan

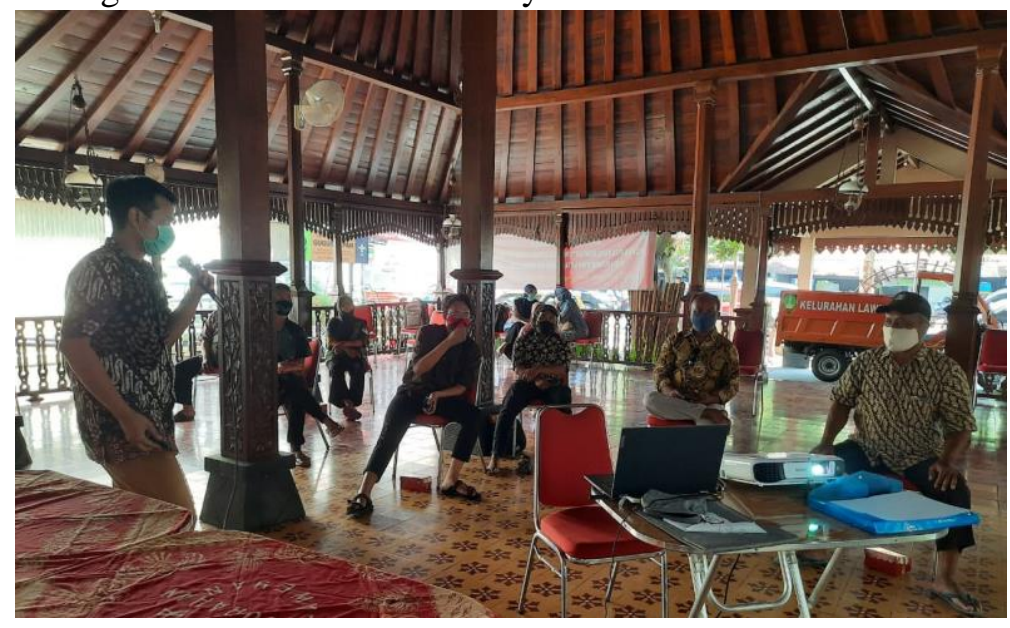

Gambar 5. Suasana Kegiatan Penyuluhan 

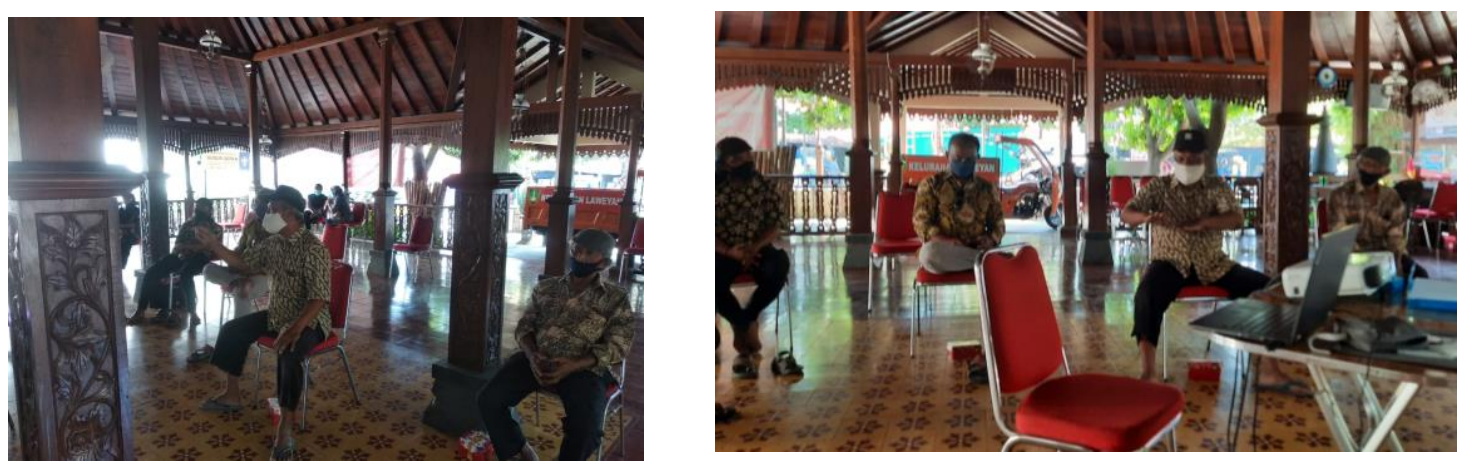

Gambar 6. Antusiasme Pengrajin Batik dalam Diskusi

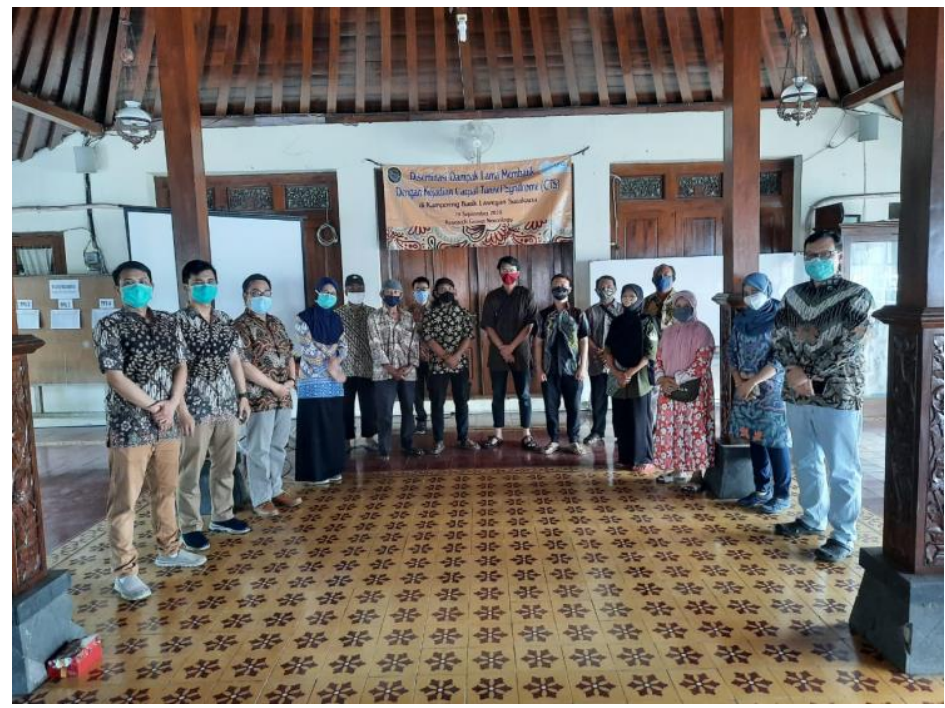

Gambar 7. Foto Bersama Setelah Kegiatan Penyuluhan

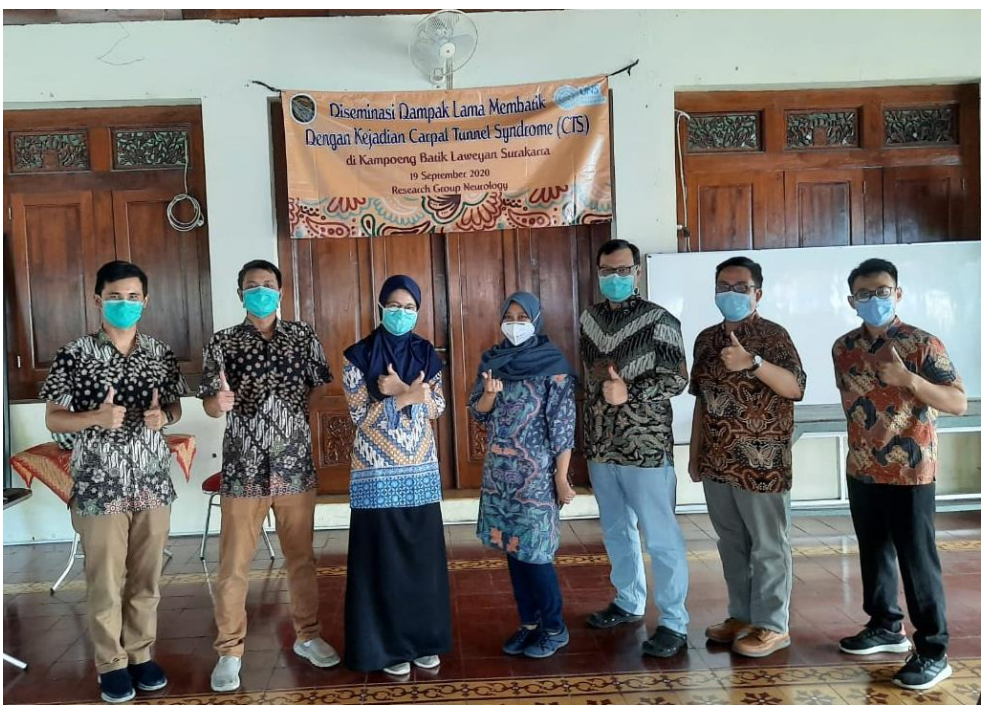

Gambar 8. Tim Pengabdian Masyarakat Neurology Research Group 


\section{HASIL DAN PEMBAHASAN}

Subjek kegiatan pengabdian masyarakat ini adalah 30 orang pengrajin batik dari Kampoeng Batik Laweyan dengan rata-rata masa kerja adalah 11,95 tahun dan rentang waktu lama kerja adalah 2-40 tahun. Rentang usia pengrajin bervariasi dengan 14 orang (47\%) berusia kurang dari 40 tahun dan 16 orang (53\%) pengrajin berusia lebih dari 40 tahun. Demografi karakteristik subjek ditampilkan pada gambar 9.

Sebelum dilakukan penyuluhan pada pengrajin batik, terlebih dahulu dilakukan evaluasi tentang pengetahuan awal pembatik terkait CTS dan posisi ergonomis dalam bekerja menggunakan kuesioner sebagai instrument. Kuesioner berisi 10 pertanyaan dengan hasil evaluasi dapat dilihat pada tabel 1. Pemberian materi dilakukan setelah pelaksanaan pretest. Materi disampaikan dengan metode ceramah dan diskusi selama 1 jam 30 menit. Sebelum berakhir pelaksanaan sosialisasi, masing-masing pengrajin batik diberikan posttest kembali dan brosur untuk edukasi kepada rekan pengrajin yang belum dapat hadir.
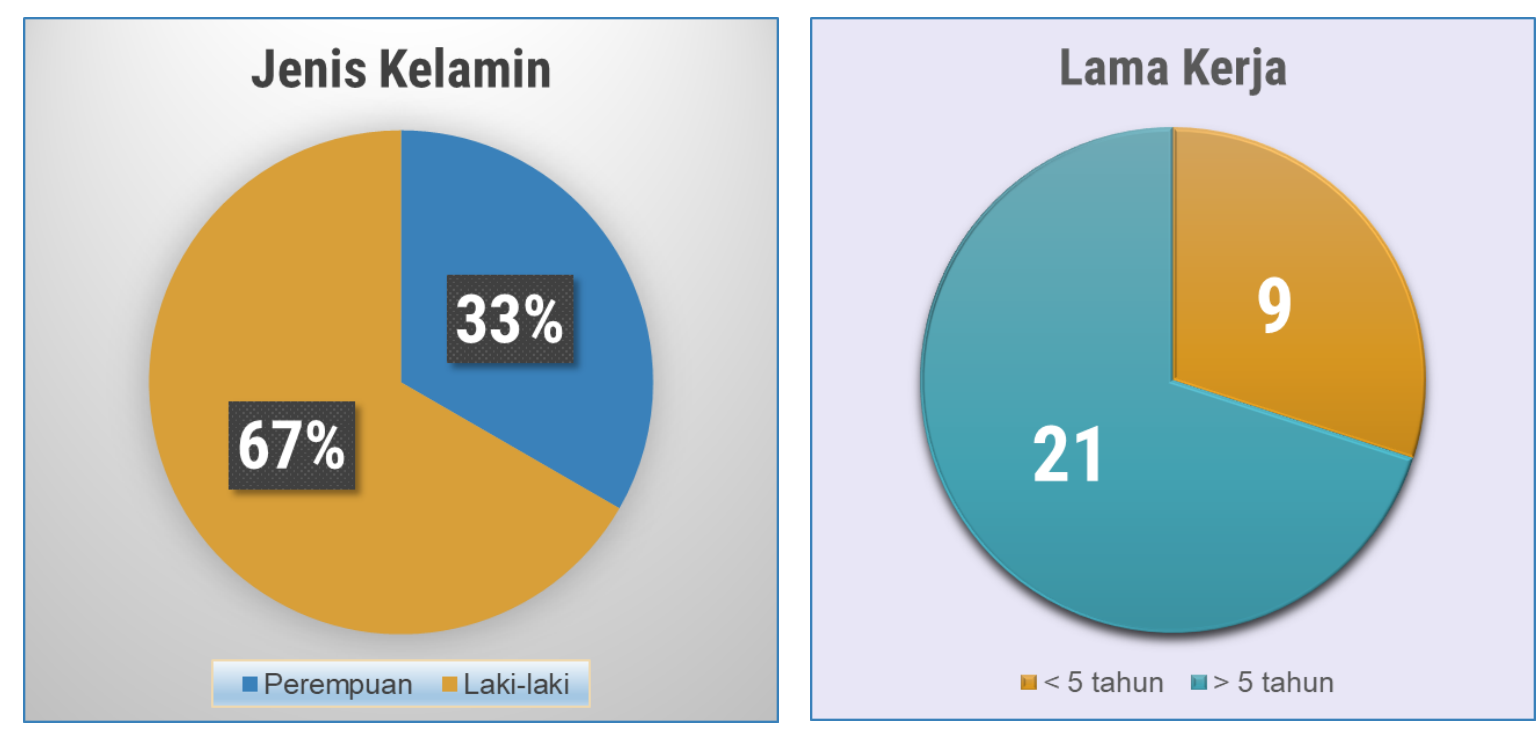

Gambar 9. Demografi Karakteristik Subjek

Tabel 1. Hasil Evaluasi Pengrajin Batik Sebelum Penyuluhan

\begin{tabular}{ccc} 
Nilai & Jumlah Pengrajin & Persentase \\
\hline 100 & 2 & $6,67 \%$ \\
90 & 3 & $10,00 \%$ \\
80 & 5 & $16,67 \%$ \\
70 & 7 & $23,33 \%$ \\
60 & 6 & $20,00 \%$ \\
50 & 4 & $13,33 \%$ \\
40 & 3 & $10,00 \%$ \\
\hline
\end{tabular}

Pada akhir pelaksanaan kegiatan, evaluasi dilakukan dengan mengukur tingkat pengetahuan pengrajin batik dengan mengerjakan posttest yang hasilnya dapat dilihat pada tabel 2 . Hasil dari penyluhan terkait dampak lama membatik, posisi ergonomis, dan pencegahan kejadian CTS pada pengrajin batik ini sudah mencapai target. Hal ini ditunjukkan dari analisis data yang menggunakan uji $\mathrm{T}$ dependen dengan variabel terikat adalah tingkat pengetahuan pengrajin batik yang diukur dari nilai pretest dan posttest serta variabel bebas adalah penyuluhan. 
Tabel 2. Hasil Evaluasi Pengrajin Batik Setelah Penyuluhan

\begin{tabular}{ccc} 
Nilai & Jumlah Pengrajin & Persentase \\
\hline 100 & 5 & $16,67 \%$ \\
90 & 6 & $20,00 \%$ \\
80 & 6 & $20,00 \%$ \\
70 & 8 & $26,67 \%$ \\
60 & 5 & $16,67 \%$ \\
50 & 0 & $0,00 \%$ \\
40 & 0 & $0,00 \%$ \\
\hline
\end{tabular}

Hasil uji T dependen menggunakan SPSS 20.0 for Windows ditunjukkan dalam tabel 3, di mana sumbangan penyuluhan terhadap peningkatan pengetahuan dan kesadaran pengrajin batik akan posisi ergonomis dan pencegahan CTS adalah 93,51\%, sedangkan sisanya yaitu 6,49\% dipengaruhi oleh faktor lain. Hasil analisis ini juga signifikan secara statistik $(\mathrm{p}=0,000)$. Selain itu selisih mean sebelum dan sesudah penyuluhan adalah 11,33 $\pm 5,07$ dan perbedaan tingkat pengetahuan yang ada signifikan secara statistik pada taraf kepercayaan $95 \%$.

Tabel 3. Hasil Analisis Uji T Dependen

Paired Samples Statistics

\begin{tabular}{|rl|r|r|r|r|}
\hline & & Mean & $\mathrm{N}$ & Std. Deviation & Std. Error Mean \\
\hline \multirow{2}{*}{ Pair 1 } & Pretest & 68.00 & 30 & 16.897 & 3.085 \\
& Postest & 79.33 & 30 & 13.629 & 2.488 \\
\hline
\end{tabular}

Paired Samples Correlations

\begin{tabular}{|ll|r|r|r|}
\hline & $\mathrm{N}$ & Correlation & \multicolumn{1}{c|}{ Sig. } \\
\hline Pair 1 & Pretest \& Postest & 30 & .967 & .000 \\
\hline
\end{tabular}

Paired Samples Test

\begin{tabular}{|c|c|c|c|c|c|c|c|c|c|}
\hline & & \multicolumn{5}{|c|}{ Paired Differences } & \multirow[t]{3}{*}{$\mathrm{t}$} & \multirow[t]{3}{*}{ df } & \multirow{3}{*}{$\begin{array}{c}\text { Sig. } \\
\text { (2-tailed) }\end{array}$} \\
\hline & & \multirow[t]{2}{*}{ Mean } & \multirow[t]{2}{*}{ Std. Deviation } & \multirow[t]{2}{*}{$\begin{array}{c}\text { Std. Error } \\
\text { Mean }\end{array}$} & \multicolumn{2}{|c|}{$\begin{array}{c}95 \% \text { Confidence Interval of } \\
\text { the Difference }\end{array}$} & & & \\
\hline & & & & & Lower & Upper & & & \\
\hline Pair 1 & $\begin{array}{l}\text { Pretest - } \\
\text { Postest }\end{array}$ & -11.333 & 5.074 & .926 & -13.228 & -9.439 & -12.234 & 29 & .000 \\
\hline
\end{tabular}

Masa kerja pengrajin batik di Kampoeng Batik Laweyan terkait dengan peningkatan kejadian CTS. Penelitian sebelumnya tidak hanya mencari tanda dan gejala klinis tetapi juga menggunakan pengukuran yang lebih obyektif dengan pemeriksaan EMG yang mengukur kecepatan hantaran saraf pengrajin batik dalam menentukan tingkat keparahan CTS, baik pada pengrajin yang mengalami tanda dan gejala CTS maupun tidak (Subandi dkk., 2020).

CTS merupakan salah satu CTD yang paling banyak dijumpai pada pekerja industri yang memiliki gerakan repetitif seperti penjahit. Dalam kegiatan pengabdian ini, peneliti memilih kelompok pengrajin batik yang juga melakukan 
gerakan repetitif. Studi lain menunjukkan bahwa CTS tidak hanya mempengaruhi pekerja industri, tetapi juga mempengaruhi pekerja lain yang melakukan gerakan berulang seperti menggunakan keyboard dan mouse computer (Maghsoudipour dkk., 2008)

Patofisiologi kerusakan jaringan saraf pada CTS merupakan kombinasi antara faktor mekanis dan iskemik (Kurniawan dkk., 2016). Secara mekanis, pembengkakan yang terjadi di sekitar terowongan karpal atau penekanan akan mempersempit terowongan karpal yang akan menyebabkan sumbatan pada serabut saraf. Hambatan pergerakan saraf pada terowongan ini akan mengakibatkan trauma ringan pada serabut saraf yang mengakibatkan edema dan iritasi. Selanjutnya proses adhesi bekas luka yang muncul akan meningkatkan tekanan lokal dan menurunkan kecepatan hantaran saraf. Secara iskemik, penekanan yang terjadi akan menyebabkan gangguan pada mikrovaskuler intraneural, sehingga aliran darah serabut saraf menjadi terhambat atau terjadi proses stasis aliran intraneural (Malibary dkk., 2013).

Hubungan yang tidak signifikan secara statistik antara masa kerja dengan keluhan pengrajin batik dapat disebabkan oleh faktor subjektivitas yang tinggi pada pengrajin batik yang tidak merasakan keluhan CTS yang timbul seperti kesemutan atau mati rasa dan hanya menyatakan keluhan setelah ada nyeri atau sensasi terbakar di telapak tangan (Subandi dkk, 2020).

Mengingat komorbiditas yang menyebabkan kerusakan nervus medianus pada pengrajin batik cukup tinggi, perlu ditelusuri faktor-faktor lain yang dapat memperparah kerusakan tersebut. Peningkatan pemahaman dan kesadaran pengrajin batik di Kampoeng Batik Laweyan yang telah tercapai melalui penyuluhan ini diharapkan dapat membantu para pengrajin memahami berbagai faktor lain seperti aktivitas atau posisi kerja sehari-hari yang dapat menyebabkan kerusakan saraf dan mengindarinya. Dengan demikian, para pengrajin batik tersebut dapat mencegah timbulnya CTS sebagai penyakit akibat kerja.

\section{KESIMPULAN}

Hasil evaluasi menunjukkan peningkatan pemahaman dan kesadaran pengrajin batik terkait pentingnya posisi ergonomis pada pembatik yang bekerja dalam waktu yang lama sebagai salah satu upaya pencegahan CTS dibandingkan sebelum diberikan penyuluhan.

\section{UCAPAN TERIMA KASIH}

Penulis mengucapkan terima kasih kepada Lembaga Penelitian dan Pengabdian Masyarakat Universitas Sebelas Maret yang telah memberi dukungan moral dan materiil terhadap program pengabdian masyarakat ini. Ucapan terima kasih juga penulis ucapkan kepada Forum Kampoeng Batik Laweyan yang telah bersedia menjadi mitra dalam kegiatan pengabdian ini.

\section{DAFTAR PUSTAKA}

1. Chan L, Turner JA, Comstock BA, Levenson LM, Hollingworth W, Heagerty PJ, et al. The Relationship between Electrodiagnostic Findings and Patient Symptoms and Function in Carpal Tunnel Syndrome. Arch Phys Med Rehabil Journal. 2007; 88:127-131. DOI: https://doi.org/10.1016/j.apmr.2006.10.013

2. Hakim AL, Tjandra R. Hubungan Tingkat Keparahan Gejala dan Status Fungsional pada Pasien Carpal Tunnel Syndrome Diukur Menggunakan Carpal Tunnel Syndrome Assessment. Jurnal Kedokteran Diponegoro. 2016; 5(3):174-187. URL: https://ejournal3.undip.ac.id/i ndex.php/medico/article/download/13082/12640

3. Harlukinita D, Suroto W, Pramesti L. Pusat Batik Solo dengan Pendekatan Kearifan Lokal Studi Kasus Kampung Batik Sondakan di Surakarta. Arsitektura; 2014; 12(1):28-31. URL: https://jurnal.uns.ac.id/Arsitek tura/article/download/15718/12652 
4. International Labor Organization (ILO). The Prevention Occupational Diseases. ISSA. Switzerland; 2013:3080

5. Kurniawan B, Siswi J, Yulianing S. Faktor Risiko Kejadian Carpal Tunnel Syndrome (CTS) pada Wanita Pemetik Melati di Desa Karangcengis Purbalingga. Jurnal Promosi Kesehatan Indonesia; 2008; 3(1):5-8. URL: https://ejournal.undip.ac.id/index.php/jpki/article/ view/2548/2258

6. Kurniawan SN, Husna M, Rasyid HA, Bilqis NE. The Relationship of Carpal Tunnel Syndrome Clinical Symptomps and Electroneuromyography Results in RSSA Malang. Malang Neurology Journal. 2016; 2(1):2429. DOI: https://dx.doi.org/10.21776/ub.mnj.20 16.002.01.5

7. Maghsoudipour M, Moghimi S, Deghaan F, Rahimpanah A. Associaton of occupational and non-occupational risk factor with the prevalence of work-related carpal tunnel syndrome. Journal of Occupational Rehabilitation; 2008. 18:152-156. DOI: https://dx.doi.or g/10.1007/s10926-008-9125-4

8. Malibary HM, Al-Najjar AT, Mohammed Yassen D, Almarzouki Abuhussain HA, Radhwi OO, Ridha Alfares Z. Clinical Profile of Carpal Tunnel Syndrome in a Teaching Hospital. Pak J Med Sci. 2013; 29(1):119-121. DOI: https://dx.doi.org/10.12669/pjms.291.2946

9. Setyawan H. Risk Factors of Carpal Tunnel Syndrome in Food-Packing Workers Karanganyar. Kesmas: National Public Health Journal. 2017; 11(3):123-126. DOI: https://dx.doi.org/10.21109/kesmas.v11i3.1185

10. Subandi, Mirawati DK, Putra SE, Hafizhan M, Susilo WA, Danuaji R. The relationship between working period of batik craftsmen and incident of carpal tunnel syndrome. Malang Neurology Journal; 2020.6:71-74. DOI: http://dx.doi.org/10.21776/ub.mnj.2020.006.02.5 